\title{
Fatigue analysis of the vehicle brake disc
}

\author{
Araç fren diskinin yorulma analizi
}

Filiz KARABUDAK ${ }^{* 1, a}$

${ }^{\text {I} G u ̈ m u ̈ s ̧ h a n e ~ U n i v e r s i t y, ~ F a c u l t y ~ o f ~ E n g i n e e r i n g ~ a n d ~ N a t u r a l ~ S c i e n c e s, ~ D e p a r t m e n t ~ o f ~ M e c h a n i c a l ~ E n g i n e e r i n g, ~ 29100, ~ G u ̈ m u ̈ s ̧ h a n e ~}$

• Geliş tarihi / Received: 05.11.2020 • • Düzeltilerek geliș tarihi / Received in revised form: 21.07.2021 • Kabul tarihi / Accepted: 08.08 .2021

\begin{abstract}
In this study, the fatigue analysis of the vehicle brake disc was simulated using the finite element program, and life calculations were made in accordance with the analysis. The main purpose is to simulate experimental tests, which take a long time to result, in the computer environment and to obtain results in a short time and at a very low cost. With the help of the ANSYS computer program, which operates with the finite element logic, the disk brake system was created in three dimensions, and the boundary conditions closest to reality were determined and analyzed using the finite element method. In the disc brake system selected, the data obtained by conducting stress, fatigue life, and safety coefficient analyses in line with the forces formed on the wheel and the vehicle during braking were examined. According to the analysis results, our brake disc is in different life ranges in accordance with the material used and the load applied, and when the force is increased, the life decreases and vice versa.
\end{abstract}

Keywords: Disc brake, Fatigue, Finite element method

\section{$\ddot{O} z$}

Bu çalışmada taşıt fren diskinin yorulma analizi sonlu elemanlar programı ile simüle edilerek analizler doğrultusunda ömür hesapları yapılmıştır. Asıl amaç sonuçlanması uzun süren deneysel testleri bilgisayar ortamında simüle edip kısa bir sürede ve çok az bir maliyetle sonuca gitmektir. Sonlu elamanlar mantığıyla çalışan ANSYS bilgisayar programı yardımıyla diskli fren sisteminin üç boyutta oluşturulması ve gerçeğe en yakın sınır şartlarının belirlenerek sonlu elaman yöntemiyle analiz yapılmıştır. Seçilen disk fren sisteminde frenleme anında tekerlek ve araç üzerinde oluşan kuvvetler doğrultusunda gerilme, yorulma ömrü, emniyet katsayısı analizleri yapılarak elde edilen veriler irdelenmiştir. Analiz sonuçlarına göre fren diskimiz kullanılan malzeme ve uygulanan yük doğrultusunda farklı ömür aralıklarında olup kuvveti arttırdı̆̆ımızda ömür düşmekte tam tersi durumda ise ömür artmaktadır.

Anahtar kelimeler: Disk freni, Yorulma, Sonlu elemanlar metodu

\footnotetext{
${ }^{{ }^{*} a}$ Filiz KARABUDAK; filizkarabudak@gumushane.edu.tr, Tel: (0456) 23310 00, orcid.org/0000-0002-7365-0333
} 


\section{Introduction}

Braking performance is one of the effective parameters, the importance of which is indisputable in terms of vehicle safety. The main factors affecting this performance are listed as follows: the design of the brake system, vehicle weight, braking efficiency of the front-rear wheels, the efficiency of the brake mechanical and hydraulic components, the environmental conditions that may affect the brake system, tires, load on the vehicle, brake settings, road condition, the friction/adhesion coefficient between the wheel and the road (Bayrakçeken and Düzgün, 2005; Güney and Mutlu, 2015).

A part that breaks suddenly in the brake system, which directly affects human life, can cause serious consequences. In automotive vehicles in which machined and cast brake discs are used, such as passenger cars, trucks, and motorcycles, heavy brake loads, difficult operating conditions, and the ongoing environmental conditions may affect the operability and performance of the device and cause fatigue failures (Norman et al., 2016).

Such a failure, which can also occur as a result of a poor design, significantly affects the fatigue damage with the inhomogeneous material structure, traveling with overload, and exceeding the life of the part part (Balaji et al., 2019). The disc brake system that we focus on in this study is an important factor in the fatigue fracture. Figure 1 presents a schematic view of the disc brake system (Fildiş et al., 2001)
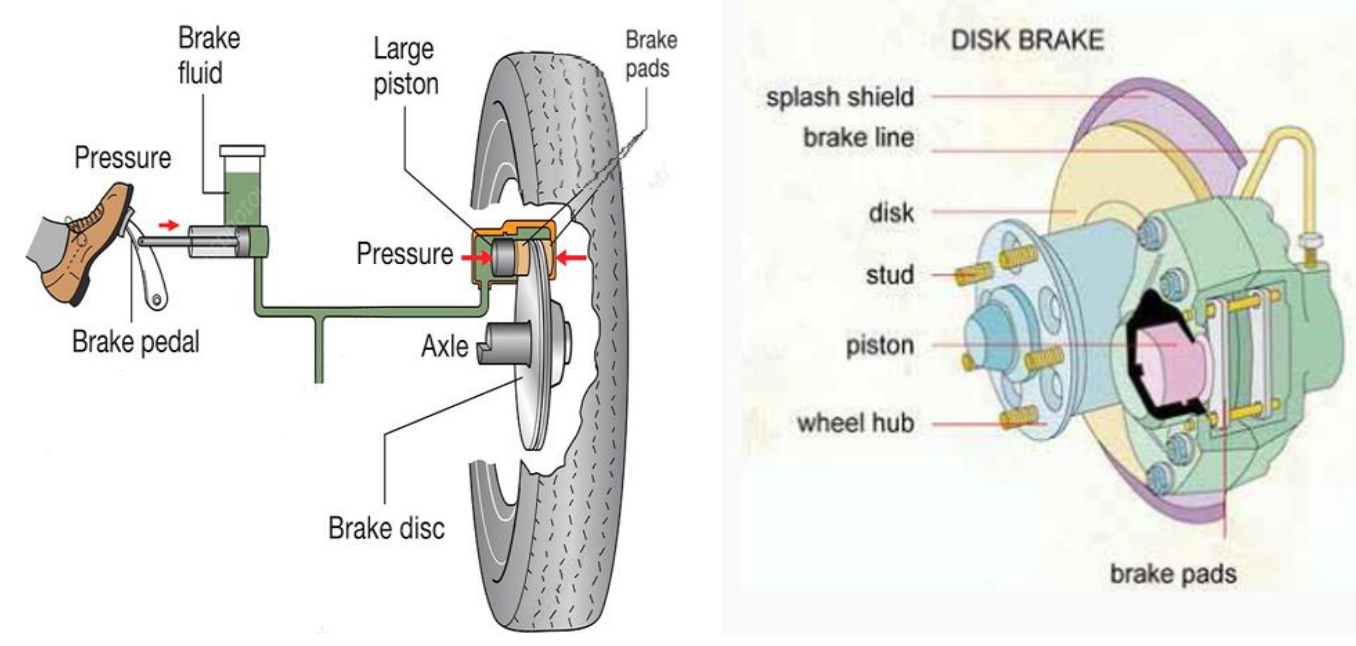

Figure 1. Schematic representation of the disk brake system

The forces affecting the wheel of the vehicle during braking in a moving vehicle are shown in Figure 2. Here, ' $\mathrm{Z}$ is the load per wheel from the vehicle weight, $\mathrm{X}$ is the reaction force of the vehicle on the wheel, Fx is the longitudinal force on the wheel, Fs is the brake friction in the wheel, $r$ is the radius of the wheel, Mt is the wheel's moment, $\mathrm{V}$ is the time derivative of acceleration, $\mathrm{Fc}$ is the load of the wheel and the reaction force of the road, and e is the distance. The distance from the axis of the impact point of the wheel load is shortened by Crouse (1973).
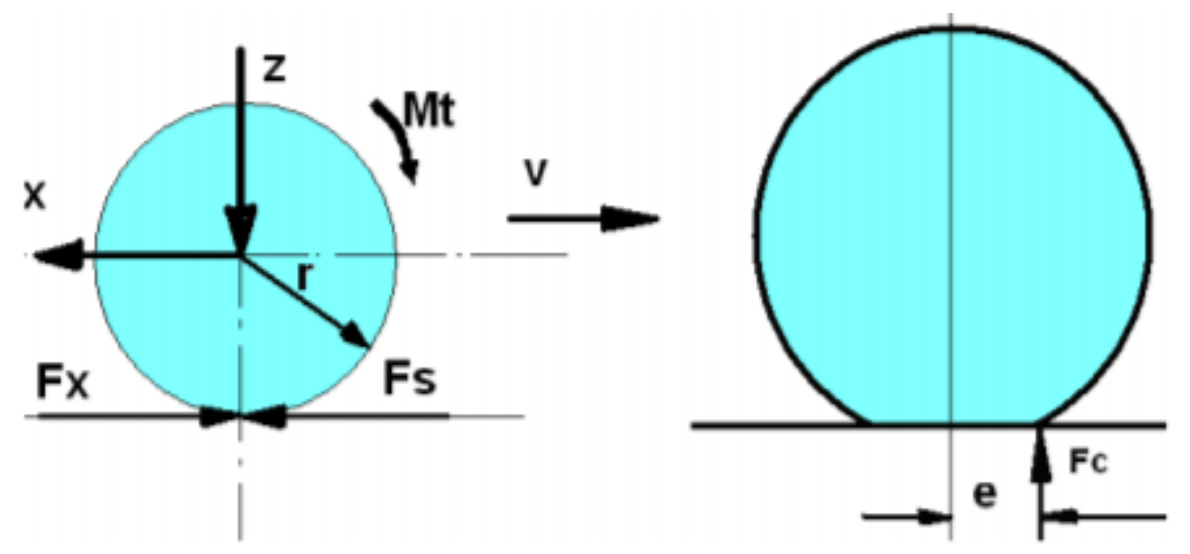

Figure 2. Forces acting on the wheel during braking (Staudt, 2000) 
The factors affecting the vehicle when the brake is applied to the vehicle while the vehicle is in motion are the friction force formed between the brake lining and the disc/drum in the brake mechanism, the friction between the road and the wheel, the force formed by the slope of the road, and the speed of the vehicle. Increasing the braking distance means an increase in vehicle speed. Friction force occurs between the brake lining and the disc in the wheel brake mechanism. It varies depending on the power of the brake system used in automobiles. The coefficient of friction between the wheel and the ground also affects braking. Since the wheels will not stop on slippery ground, the brakes will not hold much, or the wheels will slide on the ground. As a result, the braking distance of the automobile will be longer. The slope of the road changes depending on whether vehicles are going downhill or uphill. Since the force formed due to the weight of the vehicle will cause the vehicle to accelerate while going downhill, it will cause the braking distance to increase by creating a force against braking. If the vehicle goes up a ramp or a slope, the force generated by the weight of the vehicle tries to stop the vehicle this time (Pektaş, 2006).

This study was conducted to simulate the experimental tests of the fatigue analysis of disc brakes, which take a long time to result and are costly, in the computer environment and achieve results in a short time and at a low cost by conducting stress and fatigue analysis with the finite element method.

\section{Material and method}

This study focused on the disc brake system. Disc brakes provide friction with the brake pads mounted on the calipers attached to the suspension elements compressing the discs like a clamp or vise. Inside the calipers, the pistons provide pressure to the brake linings with the force they take from the center cylinder and slow down the vehicle by rubbing against the brake disc in the brake linings. Since disc brakes swing water more easily than drum brakes, they perform better under wet conditions. The channels on the disc brakes drain the water, cool more easily and are more resistant to high temperatures. However, this does not mean that they are not affected by water. If the brakes are applied when entering a puddle quickly, it is observed that the brakes do not work for the first few seconds (Köylü and Tural, 2016). There are air ducts is some discs to increase performance. By pressing the brake pedal, the center pump delivers the brake fluid to the pistons through pipes and hoses. Therefore, the brake pads on both sides press simultaneously against the disc with equal force (Bannantine et al., 1990). The force acting on the brake pedal is a measure of the amount of pressing the brake lining and thus the amount of braking. With the release of the brake, the brake pedal spring and center pump piston return to their initial position. At the same time, the pressure in the brake, pipes and hoses and wheel cylinders decreases, and the pressure forces on the brake pads disappear by being pulled back by the friction forces on the friction surfaces (Stephens et al., 2001)

Modeling the interior design of the components in the disc brake system is very important. Although the model is complex, it must be simple and easy to understand in terms of engineering. Depending on the model design, structural factors and simulation analysis can be performed, and parallel to this, static, dynamic, and other effects can be analyzed (Hancq et al., 2000). Modeling was performed in the dimensions of the brake disc, the manufacturing picture of which is given in Figure 3.

One of the convenience provided by the Ansys Workbench program is that it provides the properties of the materials frequently used in the industry (Poison.Young module, etc.). If these materials are to be used, the desired material can be selected from the window to be opened in the import button. If the material properties of the part we will analyze are not available in the Ansys Workbench database, then we need to enter it ourselves. For this reason we need to introduce the material properties in the New Material tab from the Details section. In this study, the mechanical properties of gray cast iron material used in many places such as engine castings were redefined by taking into account the fatigue graph (S-N).

From the study of Young's Modulus and Poisson ratio (Tartaglia, 2012) and for S-N diagram values Wohlfahrt et al. (2010) 's study was benefited. Dynamic fatigue analysis is performed in Ansys software by applying the load in the desired range with the defined fatigue graph values. Average load values define the maximum and minimum values of the forces acting on the wheel during braking. These forces occur between the brake lining and the disc in the wheel brake mechanism. 


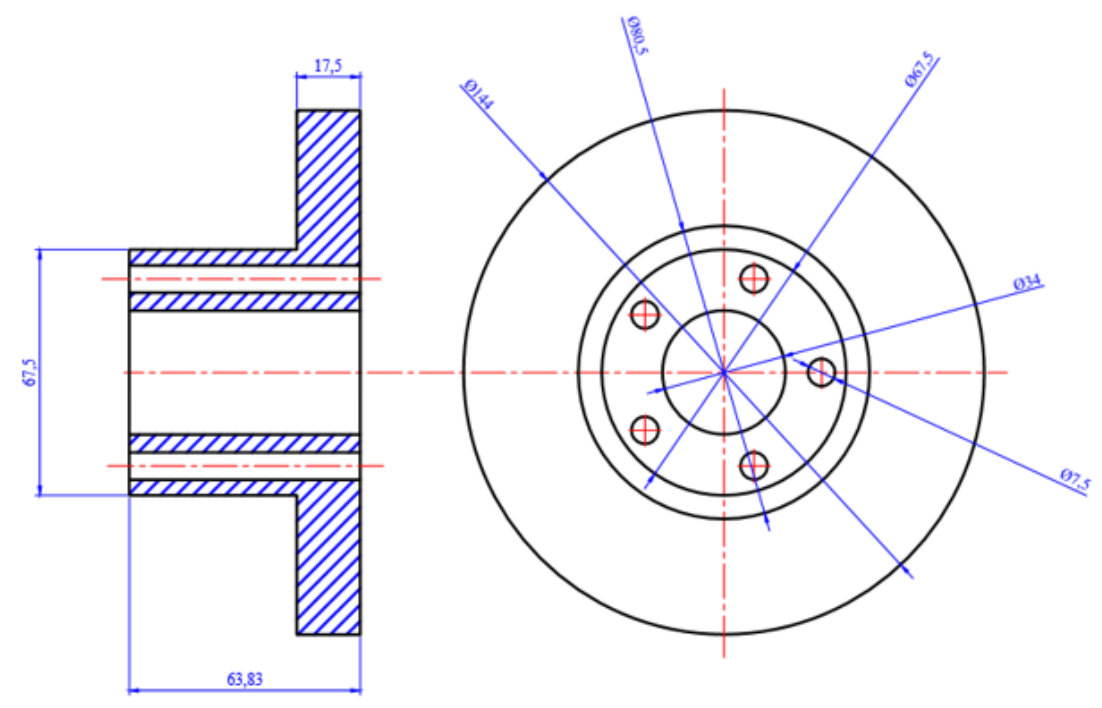

Figure 3. Technical drawing of the brake disc model

Gray cast iron, which is used in many places such as engine castings, vehicle clutch linings, and engine cylinder blocks, is also used as a brake disc material. In this study, pearlitic (G4000) gray cast iron material with the following mechanical properties, yield strength $552 \mathrm{MPa}$, modulus of elasticity $120 \mathrm{GPa}$, and Poisson's ratio 0.3, was used (Tartaglia, 2012).

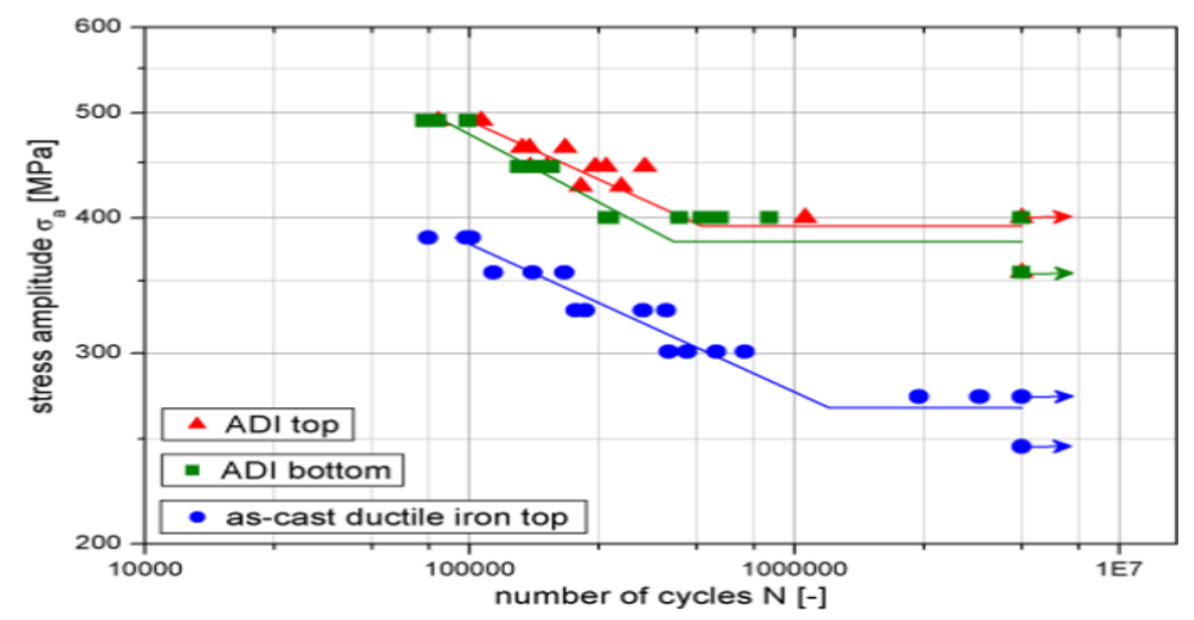

Figure 4. Gray cast iron S-N diagram (Wohlfahrt et al., 2010)

Figure 4 shows the experimental $\mathrm{S}-\mathrm{N}$ fatigue diagram of the untreated cast iron material in the curve shown in blue in the examination performed by Wohlfahrt (2010). In our study, comparisons will be made by considering this curve.

\subsection{Modeling approach}

The model represents a simplified simulation that is the closest to reality in accordance with the aim. The disc brake system consists of a fixed caliper and brake pads placed on this caliper, brake hydraulic cylinder and pistons with their shoes. The basic parts of the disc brake mechanism consist of a brake disc, caliper, brake hydraulic cylinder, and piston. The disc brake system, the working principle of which is explained in detail in the section above, is based on the Pascal principle. The mechanical force generated in the brake pedal is converted into hydraulic pressure at the brake main center, and this hydraulic pressure is converted back into mechanical force in the caliper. The motion energy of the vehicle is converted into heat energy by the pads rubbing against the disc. The disc brake system is divided into two classes as ventilated and non-ventilated disc brake systems. This study focused on the non-ventilated disc brake system. Modeling the parts and the interior design of the disc brake is important. The model created should be simple, easy, and understandable from an engineering point of view. While maintaining complex integrity, a fit to the model should also be considered. Figure 5 presents the assembly picture of the 3D model of the vehicle brake system. 


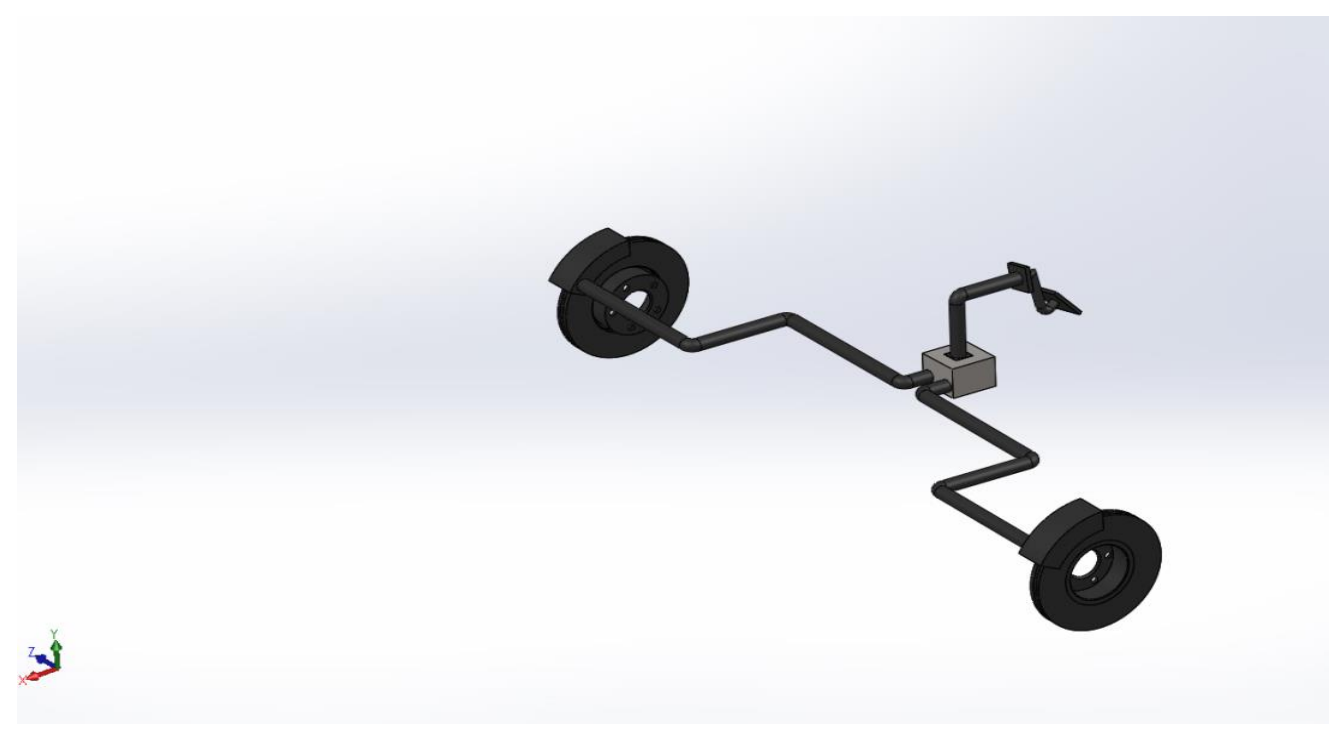

Figure 5. Three-dimensional assembly picture of the disk-brake system

After the disc brake system, the 3-dimensional model of which was completed in Solidwork software, was saved as a step file extension, it was transferred to Ansys Workbench finite element software. The material assignment was made in line with the mechanical properties of gray cast iron, and the S-N curve of Wohlfahrt (2010) was introduced to the program. Basic static structures such as equivalent von Mises stress during braking, total deformation and fatigue life will be analyzed in the brake disc with the defined mechanical properties.

\subsection{Fatigue analysis-disk brake}

As shown in Figure 6, the pearlitic (G4000) gray cast iron material was assigned to the disc brake and brake system elements, divided into finite elements in optimum dimensions.

In static analysis, to perform von Mises stress and fatigue damage analysis, after assigning the load, the solution was started by assigning life, damage, and safety factor parameters in the Fatigue tool tab for fatigue life calculation. Since gray cast iron is a brittle material, the Goodman curve was taken into account when performing fatigue analysis (Figure $6)$.

Constant Amplitude Load Fully Reversed

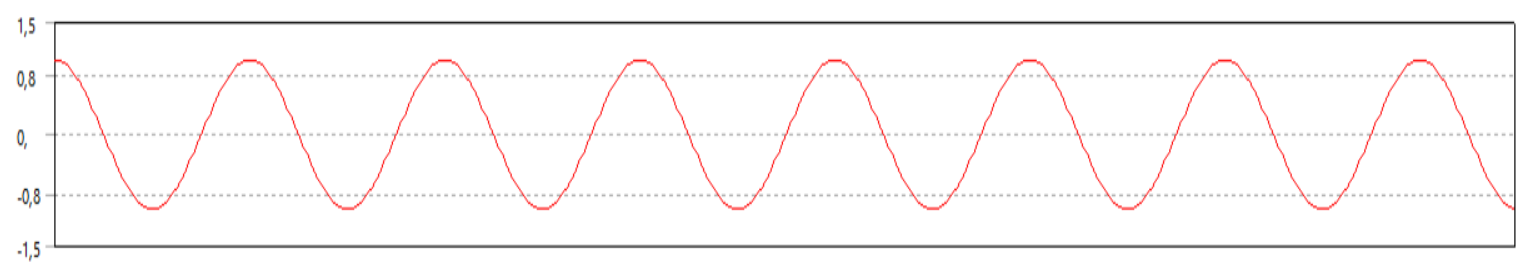

Mean Stress Correction Theory

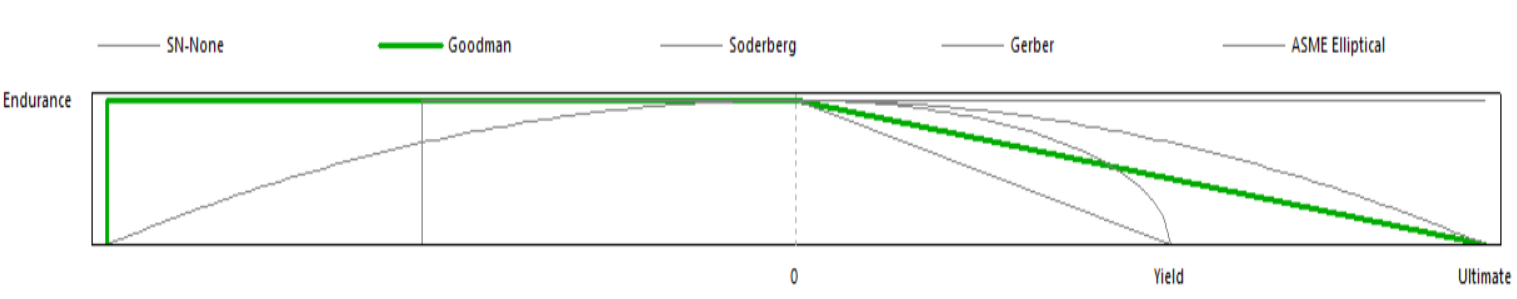

Figure 6. Goodman Curve

In the Goodman-Soderberg approach, the strength values and average stress values obtained from the static strength limit on the horizontal axis are determined. On the vertical axis, the stress amplitude and the strength limit value obtained from completely variable stress are determined. 


\section{Results and discussion}

\subsection{Total deformation and von-Mises stress} analysis

The brake caliper, which is compressed with the fixed support process, applies a $33.1 \mathrm{kN}$ payload (constant load) in the $\mathrm{Z}$ negative axis direction within the boundary conditions on the gray cast iron disc, whose mechanical properties and fatigue curve are defined. As seen in Figure 7, the maximum total deformation of $0.67051 \mathrm{~mm}$ in the disc brake element occurred at the contact points, shown in red.

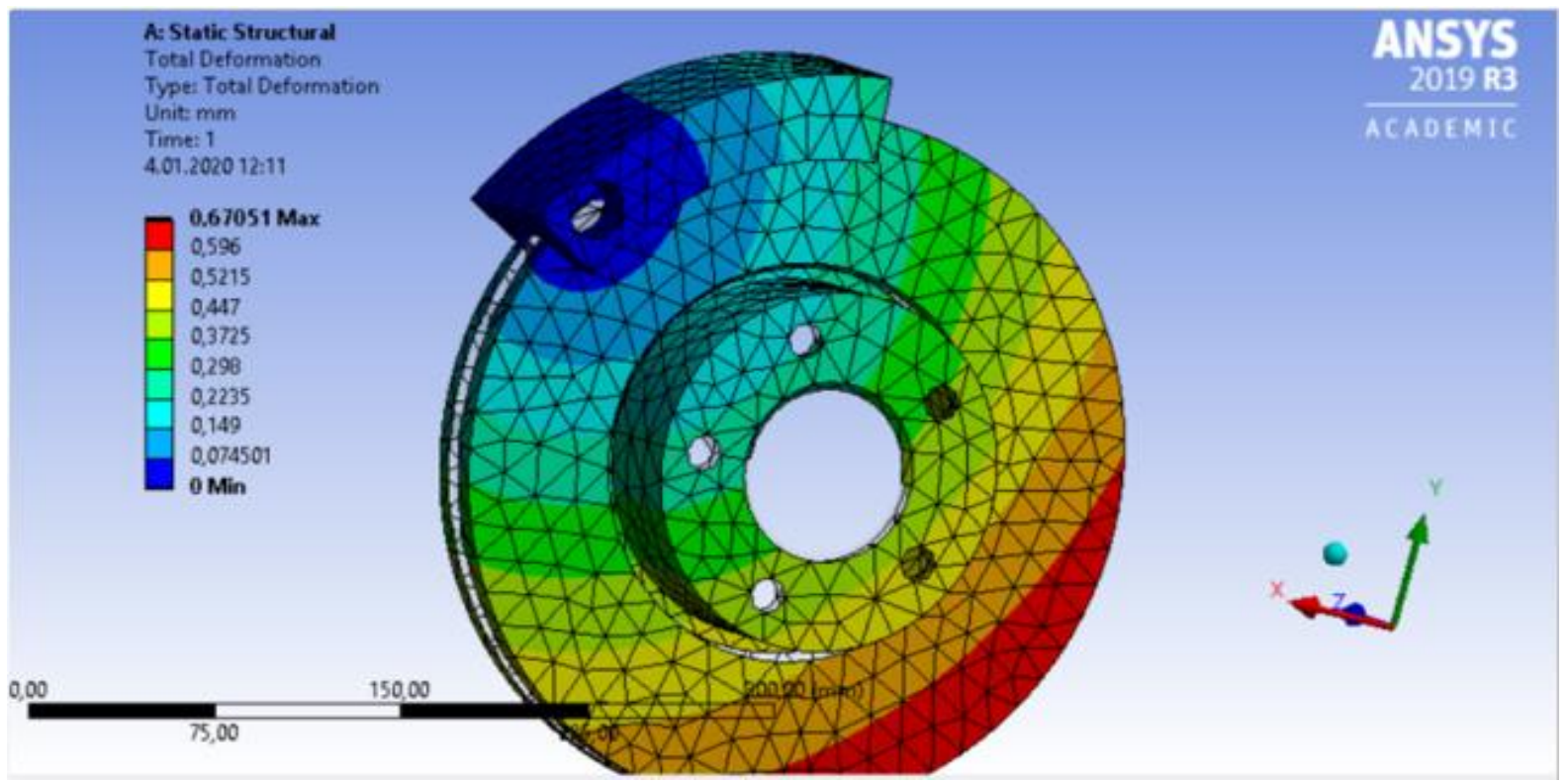

Figure 7. Total deformation in the disc brake

Under the load applied, the maximum equivalent von Mises stress value of $642.68 \mathrm{MPa}$ shown in Figure 8 occurs in the area shown in red on the contact surface of the brake pad with a disk brake. The intensity of the stresses at different points affects the load-carrying capacity and strain resistance of the materials. As seen in the figure, stress concentrations occur around the critical cross-section point. The material carries the maximum load it can carry at the points with the maximum stress concentration.

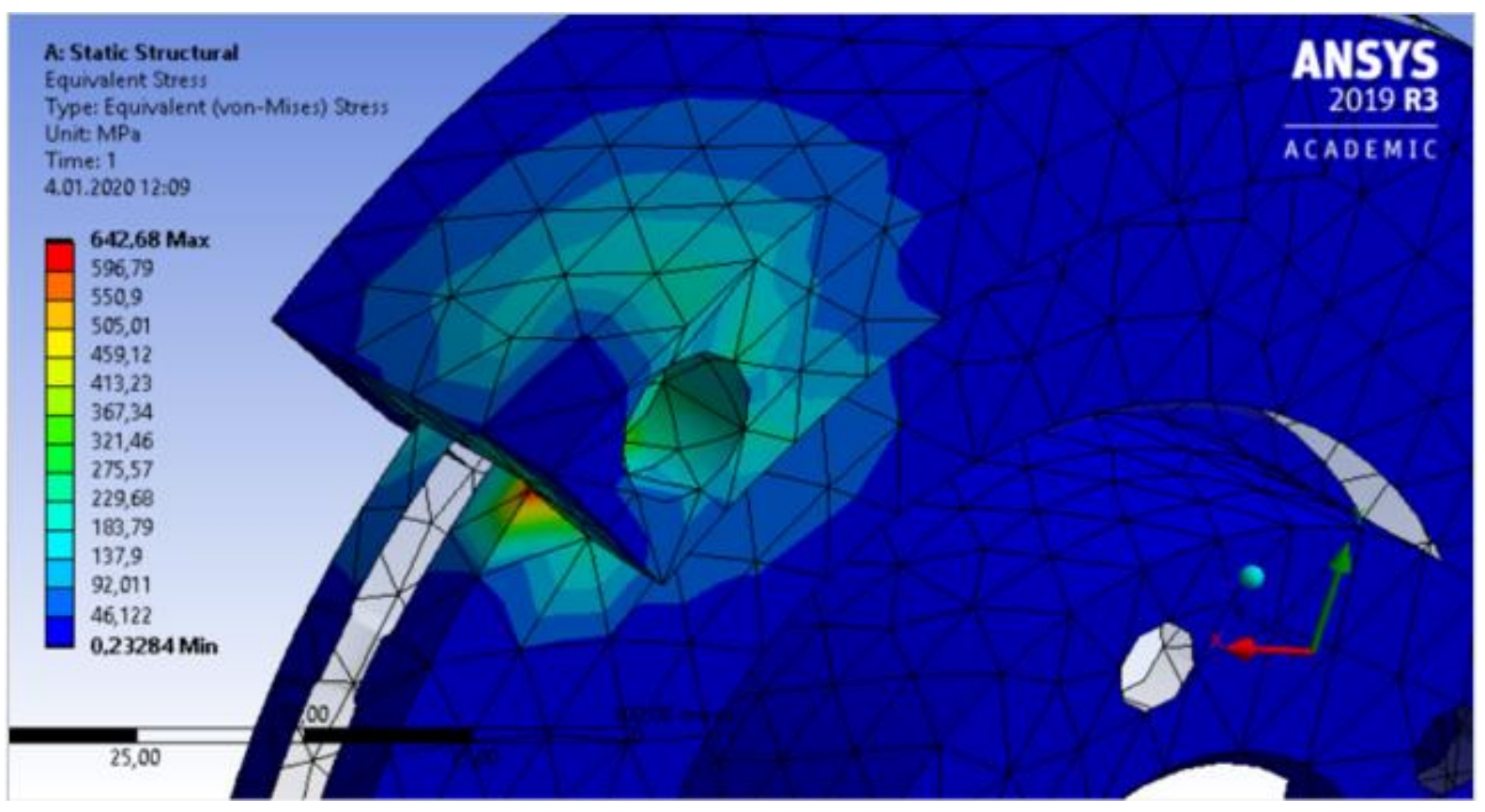

Figure 8. Equivalent von Mises stress in the disc brake 
3.2. Fatigue life, damage, safety factor and fatigue sensitivity

Upon examining the analysis results (Figure 9), it goes to infinite life in $1 * 10^{6}$ cycles. In the direction of the applied stress, fracture occurs by suffering from fatigue damage at a minimum value of 735.96. As the stress decreases, the number of cycles increases and reaches infinite life.

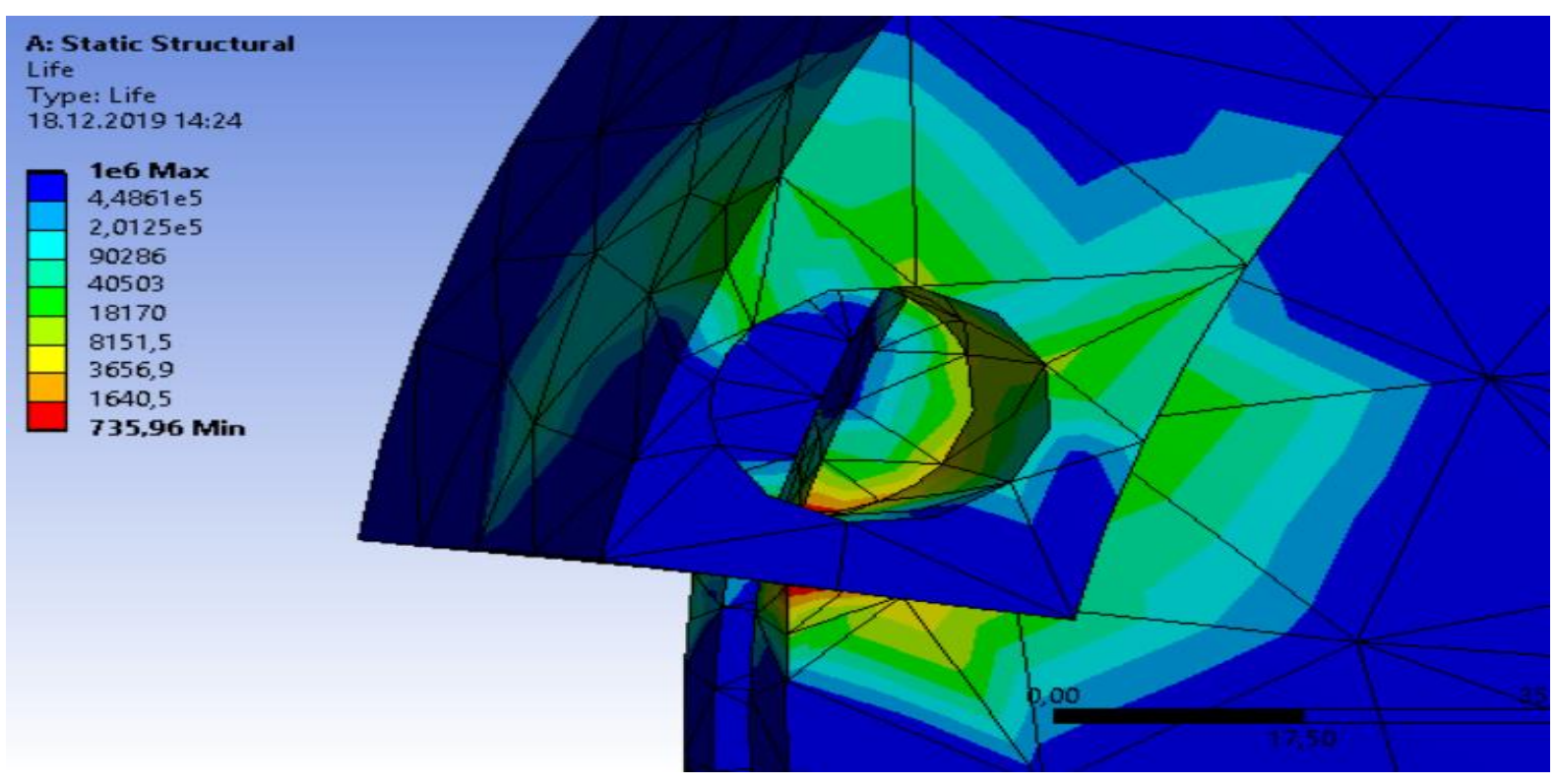

Figure 9. Fatigue life in the disc brake element

Fatigue damage is evaluated together with infinite life. It was determined that the disc brake element reached infinite life at $1 * 10^{6}$ cycles and under a stress of $300 \mathrm{MPa}$ (Figure 12). Fatigue damage occurs at all values above this stress value. As shown in Figure 8, the maximum stress value of $642.68 \mathrm{MPa}$ causes the maximum fatigue damage of 1.3588e6 (Figure 10).

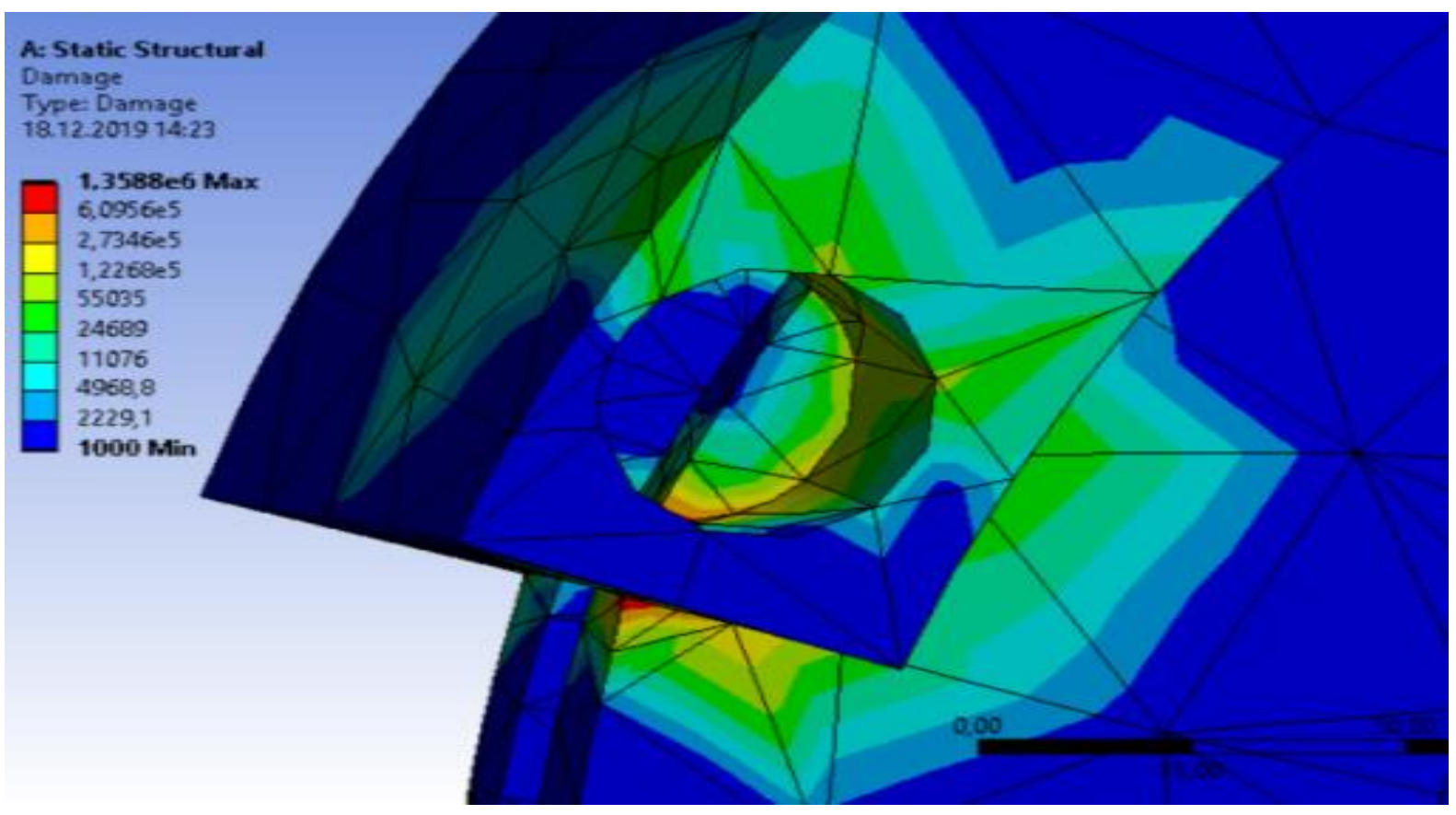

Figure 10. Fatigue damage in the disc brake element

It is observed in Figure 11 that under the current stress condition, according to the Goodman criteria, the safety coefficient is maximum 15 and minimum 0.4644. In regions where the safety coefficient is higher than 1 , there is no fracture, it is safe to the Goodman criterion, and it is observed 
to be at the stress value below the stress value at which it reaches infinite life.

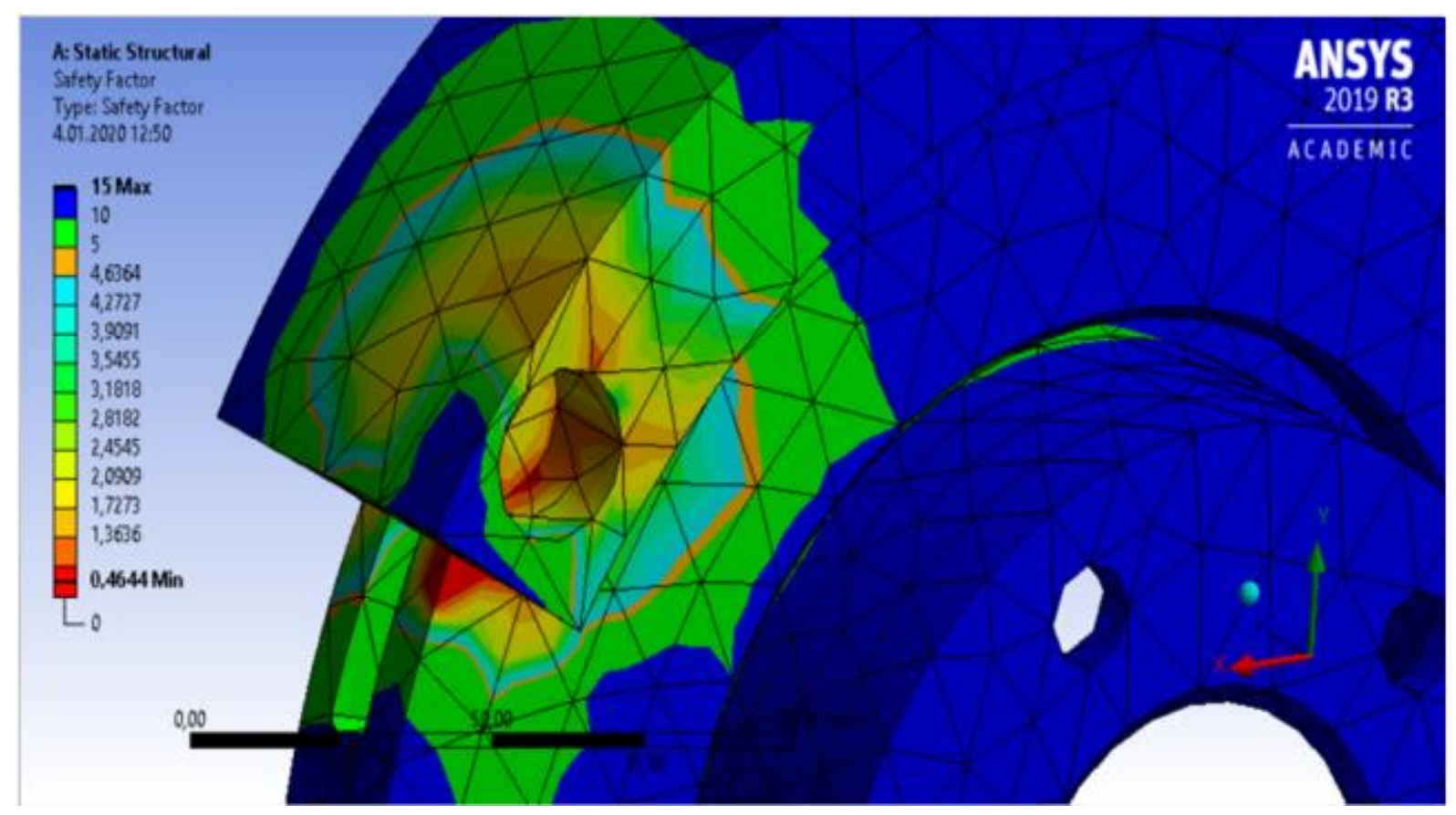

Figure 11. Safety coefficient in the disc brake element

\begin{tabular}{l|l|l} 
& \multicolumn{1}{|c|}{ B } & \multicolumn{2}{|c}{ C } \\
\hline 1 & Cycles & Alternating Stress (MPa) \\
\hline 2 & 10 & 642,68 \\
\hline 3 & 100 & 571,3 \\
\hline 4 & 1000 & 499,91 \\
\hline 5 & 10000 & 428,53 \\
\hline 6 & $1 \mathrm{E}+05$ & 367,34 \\
\hline 7 & $1 \mathrm{E}+05$ & 347,15 \\
\hline 8 & $1 \mathrm{E}+05$ & 330 \\
\hline 9 & $1 \mathrm{E}+06$ & 310,68 \\
\hline 10 & $1 \mathrm{E}+06$ & 305 \\
\hline 11 & $1 \mathrm{E}+07$ & 303,12 \\
\hline 12 & $1 \mathrm{E}+08$ & 298,46 \\
\hline$*$ & & \\
\hline
\end{tabular}

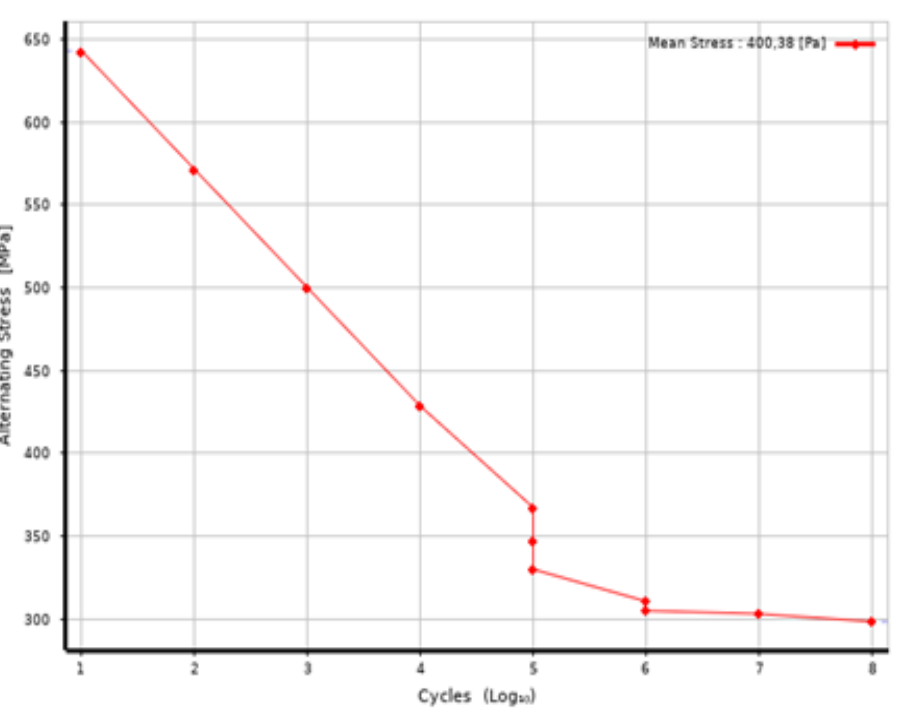

Figure 12. Disk material S-N plot

Figure 12 presents the fatigue (S-N) diagram of the disc brake element. Wohlfahrt et al. (2010) obtained theoretical results parallel to their experimental study values. When the plot was examined, it was observed that the gray cast iron brake disc reached infinite life at a stress value of $300 \mathrm{MPa}$ and in $1 * 10^{6}$ cycles. In similar literature studies of Ş1k et al. (2015), experimental fatigue strength tests of wheels in vehicles were made and simulation of the wheel was created in virtual environment based on the experimental fatigue graph with ANSYS engineering software and theoretical fatigue strength analysis was performed. When looking at the minimum number of cycles in the fatigue graph in the study, it was concluded that 1 million cycles were reached and infinite life was achieved. According to the data obtained from the analysis and test results, as the stress value applied on the material increases, the cycle number of the material decreases, and fatigue damage occurs at all stress values above its infinite life. The gray cast iron material with a yield stress 
of $552 \mathrm{MPa}$ was damaged at all values above 300 MPa yield.

\section{Conclusion}

**Under the current stress condition, according to the Goodman criteria, the safety coefficient was determined to be maximum 15 and minimum 0.4644 . If the safety coefficient is not lower than 1 , a fracture does not occur.

**Stress concentrations occur at critical points on the material. The material carries the maximum load it can carry at the points with the maximum stress concentration. It was determined that in regions where the safety coefficient was lower than 1 , critical points were broken by being exposed to fatigue damage.

**The force applied can be decreased, or the dimensions of the material can be changed to increase the safety coefficient of the material that is safe to the Goodman curve.

**With the analysis results obtained, it was observed that the G4000 gray cast iron brake disc reached infinite life in $1 * 10^{6}$ cycles under a stress of $300 \mathrm{MPa}$.

**Experimentally obtained fatigue values of gray cast iron were determined by Wohlfahrt et al. (2010) and the fatigue values we obtained theoretically in our study coincide. The value obtained experimentally according to the S-N graph and the theoretically obtained value in the S$\mathrm{N}$ graph in our study were compared Wohlfahrt et al. (2010) obtained theoretical results parallel to their experimental study values.

**Long-lasting experimental tests were simulated in the computer environment, and results were obtained in a short time and at a very low cost.

\section{References}

Balaji, R., Nadarajan, M., Selokar, A., Kumar, S. and Sivakumar, S. (2019). Modelling and analysis of disk brake under tribological behaviour of AlAl2O3 ceramic matrix composites/kevlar® 119 composite/C/SiC-carbon matrix composite/CrNi-Mo-V steel. Materials Today: Proceedings, 18 , 3415-3427. https://doi.org/10.1016/j.matpr.2019.07.269

Bannantine, J., Comer, J. and Handrock, J. (1990). Fundamentals of metal fatigue analysis. New Jersey: Prentice Hall.
Bayrakçeken, H. and Düzgün, M. (2005). Vehicles brake efficiency and braking distance analysis. Journal of Polytechnic. 8(2), 153-160. https://doi.org/10.5578/fmbd.8524

Crouse, H., 1973. Automotive chassis volume II. Ankara: MEB.

Fildiş, M., Türkmen, H., Karasu, T., Yiğit, İ. ve Berispek, M. (2001). Motorculuk bölümü şasi iş ve işlem yaprakları (4). İstanbul: MEB.

Güney, B. and Mutlu, İ. (2015). Investigation of vehicle brake testing standards applied in the EU and USA. Afyon Kocatepe University Journal of Science and Engineering, 15(015902). 7-16, https://doi.org/10.5578/fmbd.8524

Hancq, D., Walters, A. and Beuth, J. (2000). Development of an Object-Oriented Fatigue Tool. Engineering with Computers, 16, 131-144. https://doi.org/10.1007/s003660070016

Köylü, H. and Tural, E. (2016). Developing of a software for determining advanced brake failures in brakes test bench. Pamukkale University Journal of Engineering Sciences, 22(4), 267-279. https://doi.org/10.5505/pajes.2016.90692

Norman, V., Skoglund, P., Leidermark, D. and Moverare, J. (2016). The effect of superimposed high-cycle fatigue on thermo-mechanical fatigue in cast iron. International Journal of Fatigue, 88, 121-131. https://doi.org/10.1016/j.ijfatigue.2016.03.020

Pektaş, S. (2006). Simulation of on-highwaytest (chucker) for the heavy vehicle brakes by using FEA method. Master Thesis, Dokuz Eylul University Institute of Science and Technology, İzmir.

Staudt W. (2000). Motor vehicle technique, Ankara: MEB.

Stephens, R., Fatemi, A., Stephens, R. and Fuchs, H. (2001). Metal fatigue in engineering. New York: John Wiley and Sons, Inc.

Ş1k, A., Önder, M. and Korkmaz, M. (2015). Determination of fatigue strength of vehicle wheels by structural analysis. Gazi University Journal of Science Part C: Design and Technology, 3(3), 565-574.

Tartaglia, J. (2012). Comparison of monotonic and cyclic properties of ductile irons in the afs/doe strain-life fatigue database for cast iron. International Journal of Metalcasting, 6, 7-22. https://doi.org/10.1007/BF03355524

Wohlfahrt, M., Oberwinkler, C., Tunzini, S., Rauscher, A., Caballero, R. and Eichlseder, W. (2010). The role of sampling position on fatigue of 
austempered ductile iron. Procedia Engineering,

2 , https://doi.org/10.1016/j.proeng.2010.03.145
Yavuzaslan, N. (2006). Brake system at automobile and analyse. Master Thesis, Y1ld1z Technical Institute of Science and Technology, İstanbul. 